Crossroads. A Journal of English Studies 7, 4/2014, pp. 33-45

Stephen Oladele Solanke

Elizade University, Nigeria

\title{
Mythotypes and Sociological Imports in the Apartheid World of Sizwe Bansi is Dead
}

\begin{abstract}
Oppression of man by man has been a common phenomenon from time immemorial. This subjugation has mostly been subtle, insidious and debilitating, especially of the oppressed and the common people. This paper examines the apartheid South African world in Sizwe Bansi is Dead, and exposes tacit, discreet but mythically destructive avenues that Athol Fugard, Wiston Ntshona and John Kani opine oppressors have always archetypically drawn from. The paper allows that freedom is possible if the oppressed are introspective, creative, focussed, and do not get themselves lost in the 'dangerous dreams' of their oppressors. They must, like Styles, Sizwe and Buntu in the examined text, be able to create, archetypically too, like their oppressors, new songs, new myths and new weaponry and strategies to unchain themselves.
\end{abstract}

Keywords: South Africa, Athol Fugard, apartheid, mythic, archetypal, freedom, oppression.

\section{Introduction}

Across civilizations and times, people have always suffered under the oppression of others. This has been facilitated by various factors, e.g. economics, pacts, treaties, and wars. There are other covert factors that have negatively impacted and deepened this unwholesome activity in the guises of race, ethnicity and religion. The religious-cum-racial subjugation exhibited in South Africa in the twentieth century was labelled 'Apartheid'. Wrongly founded on a South African Lutheran (Biblical) premise (especially encouraged by the South African Dutch Reformed Church), apartheid became a state policy. All blacks (the original owners of the land) became subjugated, second-class citizens. 'Apartheid', a word in Dutch and Afrikaans (two South African languages of the whites), which means "separate" and "separateness" respectively, is defined by Wikipedia, the Free Encyclopaedia, as: "the status of being apart" was a system of racial segregation enforced through legislation [. . .] under which the rights of the majority black inhabitants of South Africa were curtailed and white supremacy and Afrikaner minority rule was maintained". Elucidating, Davis (2009) writes:

The apartheid laws classified people according to three major racial groups - white; Bantu, or black Africans; and Coloured, or people of mixed descent. Later, Asians, or Indians and Pakistanis, were added as a fourth category. The laws determined where members of each group could live, what jobs they could hold, and what type of education they could receive. Laws prohibited most social contact between races, authorized segregated public facilities, and denied any representation of non-whites in the national government. People who openly opposed apartheid were considered communists and the government passed strict security legislation which in effect turned South Africa into a police state. 
As André Brink (1993) posits, this researcher also thinks, in this paper, that it is time to take a retrospective look at apartheid through Athol Fugard, Wiston Ntshona and John Kani's Sizwe Bansi is Dead. Apartheid was founded on sociological inferences stipulated by the whites. Therefore, the blacks, and a few whites and coloureds who opposed and fought the policy, had to establish new but opposing sociologically-oriented mythotypes based on sociopolitical and economic premises. This paper clarifies and portrays these mythotypes as important weaponry in the struggle against oppressive regimes as they were successfully utilized against the South African apartheid policy. Writing on Ontogenic Mythotypes, G. Charles Andersen (http://mythotypes.com/index.htm) posits that mythotypes are

\begin{abstract}
encapsulated summary systems of cultural, family and personal stories containing patterns and structural elements that convey important psychic information for both senders and receivers. Most commonly, these Mythotypes are stories of gods, heroes, legends and unusual creatures. The influence they can exercise is not always benign, and can often be characterized as "control."

Frequently these Mythotypes are attached to archetypes that become seemingly synonymous with one another. The important thing to consider is that there are a limited number of Archetypal Energies, but a nearly infinite supply of Mythotypes. Some Mythotypes are preferred within specific cultural contexts, while another culture can easily attach a different gender and story to the same Archetypal Energy.
\end{abstract}

A sociological in-text analysis of the play is the examination tool for this paper. It reflects on and opens the mainly introverted and extremely symbolic scenes. The reader is introduced to the workings of apartheid: its overt and covert social, political, psychological and economic effects. These are shown in the lives of the blacks, who comprised the highest population group in the country (but suffered the most). The text, also, albeit indirectly, points out new mythical ways of fighting and gaining freedom within and outside of the system.

Textually, Styles tells the audience he became a photographer to the chagrin of his father and family (this allows him to be an independent man). Sizwe Bansi comes in wanting his photograph taken with the false name Robert Zwilinzima. The photo becomes a still photograph when taken. Through it, Sizwe is able to communicate with his wife, who he had not seen for a long time after leaving King William's Town, his native place, for Port Elizabeth to look for a job. Here, in a few days, he would be deported by the authority as he does not have a job or the permission to seek one. In secret, therefore, he lives with a friend of a friend, Buntu. Sizwe and Buntu discover the dead body of Robert. What becomes useful to them, especially Sizwe, is the dead man's work-seeker's permit. With this, Sizwe can stay in town and look for a responsible job. It also means that he, as 'Sizwe', must effectively die. This situation is turned into reality as the papers of Sizwe are burnt and those of Robert are effectively forged into becoming Sizwe's. In all of these events, the effects of apartheid are felt and portrayed, not only through the characters, but also through the dialogue, setting, thematic focus and plot

According to Campbell (1968), myths serve four functions: mystical, cosmological, pedagogical and sociological. This paper is mainly concerned with the last function sociological - and in a minor way with the pedagogical aspect. The sociological function creates, supports, opposes and encourages all types of social orders. It allows a society to create and recreate mythotypes that are relevant to its (under)development according to its pace and choices. Therefore, while societal oppressors generate and utilize 'oppressive' myths, the oppressed are also encouraged to reconstruct these to suit their own purpose: the gaining of freedom. In agreement, Malinowski (1992), a functionalist mythologist, posits that myths chart ways for social actions. In this line of argument, while answering the question, "What is Myth?", Magoulick (2013) opines that "Myths serve to explain and encourage world view and good action within society." They are usually derived from the basic human fables, actions, 
foibles and beliefs prevalent in different but specific (past and present) civilizations. These are originated, archetypically, from a common human psychic pool source. Jung (1934: 263) states that "man carries his social imperatives within himself, a prior, as an inborn necessity." It therefore, becomes universal to link a myth to different nations, peoples and civilizations. Though the story-lines and characterizations might be slightly different, the thematic focuses are usually the same (Campbell 1968). In looking at the South African apartheid problem this paper maintains that racial discriminatory happenings in that country were not new to human civilization. This is the reason apartheid mythotypes are sourceable from that common human pool, and relevant not only to its derived environment, South Africa, but to all humans. The mythopoeic fight and struggle for freedom from oppression has come under different nomenclatures (Osofisan's Morountodun, wa Thiong'o and Mugo's The Trials of Dedan Kimathi, Hussein's Kinjeketile), but this paper has compressed most under a few named mythotypes as exemplified in Sizwe Bansi is Dead.

Historically, Athol Fugard, Wiston Ntshona and John Kani, through a workshop endeavour, wrote the play Sizwe Bansi is Dead. The text, which does not address apartheid overtly, utilizes various technicalities to express aversion and proffer solutions to the policy of racial segregation. The play sprouts from, and is linked to, protest and struggle theatre. This guerrilla theatre is depicted in the text's make-up, where plays are staged spontaneously and moved around. During the workshops that added flesh to the play, and the other two plays in the Statement collection, Wikipedia reports:

\footnotetext{
the audience used $\ldots$ crying and interjecting. The plays were workshopped ... used the feedback to improve the play.... When he (Buntu) debates how Sizwe would effectively "die" and whether the sacrifice would be worth it the audience would cry out, "Go on. Do it" because they appreciated that without a pass you were effectively a non-entity.
}

This extends to the setting of the play, which is Brechtian in orientation: austere, effective, utility-oriented, with a reduction in the audience's emotional involvement (the verfremdungseffekt). This sparse and spatial setting facilitates the continuous textual actions. According to Wikipedia, "sets and props were improvised from whatever was available, which helps to explain the minimalist sets that productions of these plays utilize". There is just one basic setting on which all the actions and dialogues are super-imposed. This is Styles' Photographic Studio in the African township of New Brighton, Port Elizabeth. Throughout, the major stage description that subsists for the play runs thus:

Styles Photographic Studio in the African township of New Brighton, Port Elizabeth. Positioned prominently, the name-board: ... . Underneath this is a display of various sizes. Centre stage, a table and chair ... used for photographs because a camera on a tripod stands ready a short distance away.

There is also another table, or desk, with odds and ends of photographic equipment and an assortment of 'props' for photographs.

The setting ... and ... scenes should be as simple as possible so that the action can be continuous. (Sizwe Bansi, 3)

This paper establishes the link between a people's understanding of their oppressed position and their mind-set in finding ways out of it. It uses Sizwe Bansi is Dead as a tool to affirm that if a people can create new focuses and new myths in their struggle, freedom might not be too far from them. 


\section{Oppression through Mythotypes}

The play is a reflection of the apartheid problems Blacks faced and the manners they went about solving them. It portrays what the future portended and how they could go about achieving their dream of freedom. In their struggle against the policy, the blacks endeavoured to create many subtle ways. These became mythic as they were derivatives from their traditional cultures. These reflections of their beliefs portray the how, when, what and where the struggle would take place. Mostly, these mythotypes were understood by all, as they were people-oriented and sociologically derived. This play, according to McDonald (2006:10),

becomes all the more powerful by dint of its basis on myths that have entered the human psyche. As Freud noted with the myth of Oedipus, there are certain myths that take up residence in the human mind and soul because they reflect primitive urges.

A mythic issue played out in the text is the connection between industrialization, civilization and apartheid. In this 'modern' world of South Africa, the words 'Serf', 'Lord' and 'Serfdom' are anomalies but are synonymised in the blacks ('boys'), the whites ('baas') and the industries (the Ford Motor Plant and others), respectively. This situation is a mythical cover-up of the subjugation of the ordinary man, the conquered and the subjugated. It is an anachronistic feudal world in a supposedly industrialized and civilized country.

The car plant, an avenue of socio-economic exploitation, negates any development the blacks might ever seek in a world controlled by the whites. With its expansion, the black workers would still not benefit. Styles states: “Car plant expansion, 1.5 million rand plan'. $J a$. I'll tell you what that means [...] more machines, bigger buildings [...] never any expansion to the pay-pocket. Make me fed-up" (Sizwe Bansi, 3). It is only when those in charge pay visits that life, temporarily, changes for the over-worked but underpaid servile workers. These types of visits, usually fun-fares, produce nothing. The visit of "Mr. Henry Ford Junior Number two or whatever the hell he is" (Sizwe Bansi, 4) catches the headlines. He is "... going to see to it that the conditions of their non-white workers in Southern Africa were substantially improved" but "The talk ended in the bloody newspaper. Never in the paypacket" (Sizwe Bansi, 4). Again, the visits demand superficial changes that do not affect the lives of the workers. At Ford's, in anticipation of the visit, surface and ordinary factory changes are implemented: general cleaning, writing and painting of alert notifications, distribution of new overalls, new tools, etc. The visitors did not even look at the workers. In the end, the workers have to make up for the lost time:

One... two... three... OUT! Into the Galaxie and gone! That's all. Didn't talk to me, Mr. 'Baas' Bradley, Line Supervisor, or anybody. He didn't even look at the plant! And what did I see when those three Galaxies disappeared? The white staff at the main switchboard.

'Double speed on the line! Make up for production lost!' It ended up with us working harder that bloody day than ever before. Just because that big ... (Sizwe Bansi, 8-9).

The myth of servility and economic-deprivation, which is as ancient as man, is propagated in contemporary South Africa: a world of exploiters and the exploited, the haves and have-nots. This situation and others of its ilk are built on social deceit emanating from lack of education by the blacks. The government, through its various apartheid policies, enforces this. Though the blacks are forced to learn the language of the whites, the latter neither speak nor write those of the former. This portrays the myth of the assumed superiority of language and race. To converse with their conquered, therefore, translators like Styles are needed by the whites, even on temporary bases. This gives the impotent blacks, through Styles, a temporary superiority edge.

The myth of subjugation is propagated by keeping the blacks out of work. Without earning power, they become de-humanized, easily toyed with, and geographically restricted to 
wherever the government deems fit. Man (Sizwe), who has run out of time of staying in Port Elizabeth, and is 'endorsed' to be deported to King William's Town, states in a letter to his wife, Nowetu:

Port Elizabeth is a big place, a very big place with lots of factories but also lots of people looking for a job like me. There are so many men, Nowetu, who have left their places because they are dry and have come here to find work. (Sizwe Bansi, 22)

The women are not left out of this economic disenfranchisement. Buntu's wife "is a domestic [...] sleep-in at Kabega Park [...] only comes home weekends" (Sizwe Bansi, 23). Buntu's "Your wife is not working" statement (Sizwe Bansi, 27) gets Man (Sizwe)'s desultory reply:

The place where we stay is fifteen miles from town. There is only one shop there. Baas van Wyk. He has already got a woman working for him. King William's Town is a dry place Mr. Buntu [...] very small and too many people. (Sizwe Bansi, 27)

Only the conquerors have the economic power to employ. If the black men and women are not employed, then they become non-persons. This is the main thrust of the apartheid policy and system. This myth of oppression, a façade for under-developing and underindustrializing the blacks and their civilization, is perpetrated through the system, and iconized through various encoded economic symbols.

Another mythic issue consists of the absurdities prevalent in the apartheid world. This political dramatic text is a concretized illusion that realizes itself through the lives of the concerned blacks. In nearly all mythic stories, the absurd becomes employable in the storyteller's hands. This creates larger-than-life scenarios authenticating the cosmogonic inference and reference to the lives of the people. The absurd hero, Styles, not only encounters other absurd characters, he demonstrates absurdist tendencies and actions. These are in the guise of portraying the irrationality of, and the inherent failure embedded in, the apartheid system. The playwrights postulate that apartheid would fail just like all other xenophobic philosophies from eternity had.

The general absurdities cut across the characters (abstract and concrete), the scenes, the actions, the surreal thematic focus and the sparse setting. This situation starts with Styles' struggle to get control of his shop by attacking the cockroaches with the insecticide, Doom. Escaping this extermination process, the cockroaches, with a 'leader' - Old Professor -, organize a meeting and are inoculated: "Brothers, we face a problem of serious pollution [...] contamination! The menace appears to be called Doom! I have recommended a general inoculation of the whole community" (Sizwe Bansi, 11). The insecticide does not kill them. The improbable did the job: a little cat, Blackie, as in the South African "township, cats are insect-eaters" (Sizwe Bansi, 12). Before all these, Styles had heard the cockroaches conversing and relegating his actions, against them, into the dustbin. As the villains, they are outwitted like in any mythic story: heroes, like Styles, use unethical and unconventional means to win their adversaries and wars.

Other characters, imaginary but concrete, are dredged from the memories of Buntu, Sizwe and Styles (especially). Thus, the text's theory of concrete illusion is established. This includes the cards and movies taken. The audience sees and understands the majority of the events through Styles' imaginary pictorial anecdotes and descriptions. This imagery is painted and concretised: the audience 'feel' these card and movie characters. Through the movie, Man (Sizwe) brings the play's second cycle alive. Becoming a reality, Sizwe walks out of the picture (through the instrumentality of Man) while dictating a letter to his wife, Nowetu. At the end, his movie-picture is taken. The more bizarre the actions and scenes, the more effective the thematic focus and direction become. 
In death, Outa Jacob fulfils the "terms of his contract with God" (Sizwe Bansi, 28). Death and dying, a contract between a human and God, is only executed when the human dies. The human cannot escape because "wherever Man is, or whatever he does, he is never without his faithful companion, Death" (Sizwe Bansi, 28). This is likened to the Native Identity Card coerced on the blacks. It must always be on them: dead or alive. Freedom is achieved only when they are dead, having "reached Home .... The only time we'll find peace is when they dig a hole for us and press our face into the earth" (Sizwe Bansi, 28).

Another mythic issue, the loss and acquisition of identity encoded in the dream of reality and freedom, is textually concretised. The apartheid system is configured to achieve the depersonalization, deprivation and dehumanization of the black and other minority populace. To achieve this, the policy attacks different levels of the people's consciousness and psyche.

The languages of the ethnically diverse blacks become anathema. They are not to be spoken in official and educational environments. With this, the blacks are deprived of their hereditary communicative media. Therefore, the only time Styles is 'employed' as a translator becomes for him a time of vengeance. But it is an ineffectual strike at the policy. The whites neither speak nor write the language(s) of the blacks. On the other hand, the blacks must speak and write the language(s) of the whites. This situation is vividly captured in the writing scene between Styles and Baas Bradley. This language imposition is mythical: it is meant to suppress the culture and traditions of the conquered. Therefore, getting Baas Bradley in a kneeling position while he stands, gives Styles his own pound of flesh. With this, McDonald (2006:18) suggests:

\section{John and Winston used the literature imported by their colonial "masters" as a weapon for counterattack. Ironically, this literature [ . . ] has subverted the colonial masters' intentions of teaching them the meaning of human rights rather than playing the pacifying and "civilizing" role the colonizers intended.}

Economically, the dictum is that of 'he who pays the piper dictates the tune.' The whites own the major economic and employing avenues. The blacks are at their mercies and caprices. Baas Bradley says that Mr. Henry Ford Junior, "the owner of this place, is going to visit us. Mr. Ford is the big Baas. He owns the plant and everything in it" (Sizwe Bansi, 7). In the Kafkaesque discussion between Man and Buntu about employment, it is discovered that without a white's legal backing, hardly can a black get any profitable job.

\footnotetext{
Buntu: Do you know any white man who's prepared to give you a job?

Man: No. I don't know any white man.

Buntu: Pity. We might have been able to work something out then. You talk to the white man, you see, and ask him to write a letter saying he's got a job for you. (Sizwe Bansi, 25)
}

With this letter, Man will still need to go through a bureaucratic labyrinth before being excluded from 'raids'. Without this, the only options left are the mines where the whites "don't worry about Influx Control", as "many black men get killed when the rocks fall. You can die there" (Sizwe Bansi, 26). Those who work in established institutions, like Ford Motors, get a "Gold-wrist watch in twenty-five years' time when they sign you off because you're too old for anything anymore" (Sizwe Bansi, 9). Clarifying this situation, which affected South African blacks and is still affecting most citizens on the African continent, as instituted by the colonial rulers and neo-colonial institutions, Walter Rodney (1972:122) states: 
The element of subordination and dependence is crucial to an understanding of African underdevelopment today .... It is also worth noting that there is a type of false or pseudo integration which is a camouflage for development.

The Influx Control, a negatively skewed policy of repatriation, which limits and cuts off blacks from lucrative economic environments and cities, employs the raiding system to flush out and return them to their original dead-ends. Icons of servility and repression are established in mythic archetypal symbols falsely enmeshed in high population number and control policies. Blacks are raided, as happens to Man (Sizwe). This keeps them pinned to specific environments: their rights to movement, and by extension, to good jobs is denied. Dennis Brutus (Solanke, 2005: 6), the South Africa poet, in his rebellious poem, "A troubadour I traverse ...," succinctly captures this state of affairs:

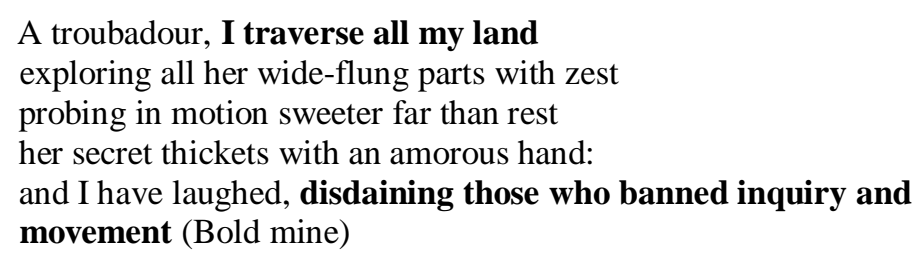

The ordinary man is immersed in the apartheid world through various documentations. To be recognized as a person, he must have a social number on his Native Identification Card: "It's more important than your name" (Sizwe Bansi, 29). It must always be on the black wherever he is, or if he gets arrested. Without it, he is a non-person, as the "white man at the Labour Bureau takes the book, looks at it - doesn't look at you!" (Sizwe Bansi, 25). The passbook allows him to stay in specific places the government deems fit: "But if that book says go, you go" (Sizwe Bansi, 24). His pink card is his record card at the Labour Bureau. According to Buntu, "Your whole bloody life is written down on that" (Sizwe Bansi, 24). To become a trader, a Hawker's License must be acquired. A Residence Permit, which allows one to stay in a place and escape raids, must be signed. Buntu elaborates the torturous, if not impossible, process of getting this (Sizwe Bansi, 25-26). Styles had to get official permission before opening and operating his photographic studio. The black man must do all these things to stay out of trouble. But Man expounds on the impossibility of not falling into trouble: "A Blackman stay out of trouble? Impossible, Buntu. Our skin is trouble" (Sizwe Bansi, 43).

The blacks are depersonalized, debased, de-organized and de-humanized. Their personalities become that of the slave, and they must always "hide your feelings" (Sizwe Bansi, 7); "clean your face" (Sizwe Bansi, 42); and "adopt a fawning, servile pose in front of the white man" (Sizwe Bansi, 43). The whites see majority of the blacks as thieves: "the old Security Guard [...] who every time he saw a black man walk past with his hands in his pocket [...] saw another spark-plug walk out of the plant" (Sizwe Bansi, 8). In his mocking and satirical translation for Baas Bradley, Styles captures it all:

\footnotetext{
Gentlemen, he says that when the door opens and his grandmother walks in you must see to it that you are wearing a mask of smiles. Hide your true feelings, brothers. You must sing. The joyous songs of the days of old before we had fools like this one next to me to worry about. (Sizwe Bansi, 7)
}

To achieve individual, group, national and racial identity, the blacks and the other minority groups, at different levels and with different results, attack and attempt to alleviate the effects of the apartheid system on their communal life. Through these, their dream of freedom could be achieved either in the long or short term. Styles breaks from the ordinary track, becomes self-employed, making his photographic studio "a story-room of dreams" (Sizwe Bansi, 12) for himself and his people. He becomes the mythic hero serving as a conduit for people's dreams and achievements (personal or group). An example of this 
achievement is the academic man who gets a standard six certificate at the age of forty-eight after seven years of study (he would become a boss-boy) and who tells Styles: "But I am not finished. I'm going to take up for the Junior Certificate, then Matric [...] and you watch, Mr. Styles. One day I walk out of my house, graduate, self-made" (Sizwe Bansi, 14) (Bold mine).

Styles keeps history alive through the family cards he takes. A photo, consisting of "my father, my mother, my brothers and sisters, their wives and husbands, our children. Twentyseven of us" (Sizwe Bansi, 15), captures, through the grandfather, the past, present and future of the African world. Through Styles, Man as Sizwe dies but resurrects as Robert, achieving temporary psycho-cultural freedom for himself and his family. Buntu, who understands the policy, meets Sizwe through and in the picture, and helps refocuses Sizwe's consciousness and ego to living within and accepting the system. Styles' father fought for South Africa in the Second World War, "So that this country and all the others could stay Free" (Sizwe Bansi, 17). On returning, he is denied the freedom he risked his life to get for others. In an ironic compensation, he is given a scoff-tin and a bicycle. His freedom ends "in a rotten old suitcase amongst some of his old rags" (Sizwe Bansi, 19) when he dies.

Politically, the struggle leads to the independence of a part of the country. This is farcical and of no use, as explained by Man: "when a car passes or the wind blows up the dust, Ciskeian Independence makes you cough ... . put a man in a pondok and call that independence? ... Ciskeian independence is shit!" (Sizwe Bansi, 31). This type of pseudo neocolonialism was practiced by a few colonial governments which ruled the various Africa countries. Kenya got her 'majimboism', and Nigeria her regional governments. This policy of region-by-region, district by district, or piecemeal independence was meant to swindle the people into believing that independence had being given. It implanted separation and tribal segregation among the people. Reacting to this type of situation, Kimathi, the hero in The Trial of Dedan Kimathi by Ngugi wa Thiong'o and Micere Githae Mugo (1976:46), exclaims:

Would you too call the war for national liberation a regional movement? What has colonialism done to your thinking? Hear me. Kenya is one indivisible whole. The cause we fight for is larger than provinces: it shatters ethnic barriers. It is a whole people's cause.

In their exploration of the myth of oppression, Athol Fugard, Wiston Ntshona and John Kani utilize multifarious nomenclatures. These portray the oppressed and the oppressors. 'Baas' and 'Makulu Baas' are used for whites only. They demonstrate the existence and omnipresence of the apartheid system, just like in George Orwell's 1984, where Big Brother, omnipresent-like, straddles Oceania. The blacks are brainwashed to a level that when Bansi is addressed as 'Mister' (Sizwe Bansi, 29), he is shocked into laughter, and questions: 'How can a black like him be referred to as Mister Bansi?' Generally, the black adults are called 'boys', irrespective of age, by any white (also irrespective of age): "[...] his little child calls you 'Boy'[...] you a man, circumcised with a wife and four children" (Sizwe Bansi, 38).

The 'respect' for any black comes when he is promoted at work. He becomes and is called "boss-boy" (the head of the boys). Due to all these, Buntu advocates a non-entity, noname situation for all South African blacks. Athol Fugard, Wiston Ntshona and John Kani's agree. This is the main reason the playwrights use Man (without a specific name) to showcase his belief that freedom is achievable by any or all the blacks. Again, the name, Styles, comes in the plurality, with the intention that this main character represents the different forms of oppression and freedom the blacks undergo and can achieve, respectively. All names are useless as all blacks are "ghosts" (Sizwe Bansi, 38) to the whites. To Buntu, therefore, "Shit on names, man! To hell with them if in exchange you can get a piece of bread for your stomach and a blanket in winter" (Sizwe Bansi, 43). What is necessary and important is staying alive and achieving one's goals within the system. This, in the final analysis, is why 
Bansi is called 'Sizwe', translated as 'Brother'. Brother Bansi dies, loses his name, but resurrects with another name, becoming a ghost with the ability to live within the system. According to Buntu, "All I'm saying is be a real ghost, if that is what they want, what they've turned us into" (Sizwe Bansi, 38).

Two individuals/actors play the three characters involved in the play. With this experimentation, play-acting and role-play come in. In the mythic world, heroes and villains are usually few, with a high number of supporting staff and hangers-on. Athol Fugard, Wiston Ntshona and John Kani utilize this technique to portray the non-importance of independence, if and when one is still dependent on another or on an external force (individual/group or official/unofficial) apart from oneself (Kinjeketile, 1970). On the other hand, it becomes an initiatory tool in the hands of Buntu in the hypnotization and conviction of Sizwe. Through it, the oppressed can for a time become free; Styles translates for Bradley; Sizwe becomes Robert. Surmising, Brink (1993:10) posits:

\begin{abstract}
It represents, in fact, the most basic function of the writer in a closed society where "normal" artistic creation is inhibited and everything is politicized: the need to record, the need to bear witness. It is the primary reaction, which precedes all resistance.
\end{abstract}

\title{
Solutions in Mythotypes
}

The text advocates a few ways out of the imbroglio. The cat that eats cockroaches depicts a struggle, a fighting policy and strategy unlike those of the past. This is exemplified in how Sizwe becomes Robert. Returning from Sky's place in the night, Sizwe and Buntu get lost. After debating how to move, they took, according to the text's direction, "An appropriate change in direction. They continue walking and eventually arrive at a square, with roads, leading off in many directions" (Sizwe Bansi, 31) (Bold mine). From here, Buntu not only finds the way, but he also discovers the body of Robert. Through this, Sizwe gets his new lease on life. This portends a future of independence and freedom for the people from the ashes of their former struggles and dead lives.

Another freedom-related mythic issue thrashed out in the text dictates that in the contemporary life envisioned in modern revolutions, there is the demystification of the supernatural forces in man's struggle for freedom. This focus shows explicitly the complexity of man's ambivalence and contradiction: man as man's enemy and friend, oppressor and saviour, concurrently. Man is chained and bound by man: it is only man that can release man from his oppressive psycho-social, political and economic bondage. The tools of unbinding himself surround him: he only needs to be creative, determined and focused.

When Styles finds cockroaches inhabiting his new shop he directly goes for the obvious solution: an insecticide. In his failure, creativeness and a change in his fighting strategy comes into play. He finds a lasting solution to his periplaneta americana problem as he comes across a cat that could do the job. Metaphorically, the cat is suggestive of new solutions black South Africans must look for. It is prophetic because it was not until all the military and violent struggles ended and dialogue ensued that relief came for South Africa.

To make Sizwe come alive in Robert, no ritualistic hullabaloo and religious chants are needed. The transformation becomes modern through a change of official identification numbers and information encompassed in an official document. Calling on gods to effect spiritual and physical changes in the human environment no longer hold total sway. Man must dance to the tune of his contemporary world; he must look into and outside of himself while consigning the gods to the nether world. The apartheid problem, falsely rooted in Christian doctrine, was created by men (legitimized during the tenure of the South African President, 
Dr. Daniel Malan in 1948 and maintained by other prime ministers and presidents like Hendrik Verwoerd, B. J Vorster and Pieter Botha). It was, therefore, pertinent for it to be resolved by men (through the instrumentalities of leaders like Frederik Willem de Klerk, Steve Biko, Nelson Mandela, Oliver Tambo and Thabo Mbeki). Spiritual aids were not very much needed, but the physical struggle and oneness of the people were.

\section{Conclusion}

Oppressors get into people's lives through various avenues: religion, culture, diplomatic pacts and deals, deceit, trade, propaganda, defeat in war and other ways. This myth of oppression has stayed with man for eons. In the developing African world, oppressors have been internal and external (Alain 2000). The internal ones have been Africans, especially after the different countries got independence from their colonial rulers; a sort of self-imposed neo-colonialism. The external ones have been colonizers of different types and from different countries of other continents. Both use oppressive tools to suppress the people: all based on false propaganda and double talk. The attempt is always to break and split the societies concerned.

Styles, Sizwe and Buntu, the major and symbolic characters, personally seek ways out for themselves and their people in this constricted, apartheid environment. Athol Fugard, Wiston Ntshona and John Kani, therefore, succeed in intertwining the characters and the thematic focus of Sizwe Bansi is Dead with mythical techniques and icons. They succeed in exposing and exploiting the mythical within an oppressive society. This results in the condemnation of apartheid without a mention of it. One can agree with Rich (2002) that the text is "lyrical in design, shattering in impact." The playwrights have been able to examine the various aspects of the political imbroglio of their society with penetrative and in-depth analytical dramatic scenes, icons and different mythotypes.

Styles is the griot telling the story of his people. It is through him, his actions and life that acquaintance is made with all facets of apartheid. The future is also predicated on him. $\mathrm{He}$, therefore, represents not only for himself but also for his race and nation an achievable future; free of racial prejudice and oppression. This, in practice, agrees with Brink's (1993:6) position: "Inasmuch as individual action can make a difference, Sizwe Bansi is far more hopeful and optimistic." The text prophesies the future of apartheid, optimistically professing new ways and methods of achieving freedom. These in reality have happened. For the herocharacters, Begiebing's (1984: 202) summation is relevant here: "By his violent journey into a mysterious and misunderstood dimension, the hero gains a wisdom that could, but probably will not, be the salvation of his species". Sizwe and the other characters are able to point the way(s) out for their people. They are able to experience and to gain the 'wisdom' to help their society through personal and group adventures.

\section{References}

Alain, R. 2000. Ebrahim Hussein: Swahili Theatre and Individualism. Dar es Salaam: Mkuki naNyota Publishers.

Andersen Charles G. "Ontogenic Mythotypes". http://mythotypes.com/index.htm. (26 June 2015)

Begiebing, Robert J. 1984. "The Mythic Hero In H. G. Wells's The Time Machine." Essays In Literature 11.2. 201-210. America: Western Illinois University. 
Brink, Andre. 1993. "No Way Out." Sizwe Bansi Is Dead and the Dilemma of Political Drama in South Africa. Athol Fugard Issue. America: Twentieth Century Literature. Winter. Vol 39, Nov.

Campbell, Joseph. 1968. The Hero With A Thousand Faces. Princeton: Princeton University Press.

Davis, Richard. H. 2008.“Apartheid.” Microsoft ${ }^{\circledR E n c a r t a}{ }^{\circledR} 2009$ [DVD]. Redmond, WA: Microsoft Corporation.

Fugard, Athol, Ntshona, Wiston and Kani, John. 1974. Sizwe Bansi Is Dead. London: Oxford University Press.

Hussein, Ebrahim. N. 1970. Kinjeketile. Nairobi: Oxford University Press.

Jung, C.G. 1934. Collected Papers In Analytical Psychology. London: Balliere, Tindall \& Cox.

Magoulick, Mary. 2013. "What Is Myth.” www.faculty.de.gsc.edu/ mmagouli/demyth.htm. (4 April 2013).

Malinowski, Bronislaw. 1992 Magic, Science and Religion and Other Essays. Prospect Heights, Ill: Waveland Press, Inc.

McDonald, M. 2006. "The Return of the Myth: Athol Fugard and the Classics." Akroterion 51. 1-19.

Orwell, George. 1950. 1984. New York: Signet Book.

Osofisan, F. 1982. Morountodun and Other Plays. Nigeria: Longman

Rich, Frank. 2002. www.drama.cmu.edu>News\&Events>Calendar. (13 February, 2013).

Rodney, Walter. 1972:122. How Europe Underdeveloped Africa. London: Bogle-L'Ouverture Publications.

Solanke, S. O. 2005: 6. 28 Poetic Voices. Nigeria: Blue Grass Ventures.

wa Thiong'o, N and Mugo, M. G. 1976. The Trial of Dedan Kimathi. London: Heinemann.

Wikipedia.org. 2013.www.en.wikipedia.org/wiki/Athol_Fugard. (10 February 2013).

Wikipedia, the Free Encyclopaedia. 2013. "Apartheid in South Africa." www.en.wikipedia.org/wiki/Apartheid_in_South_Africa. (26 March 2013) 